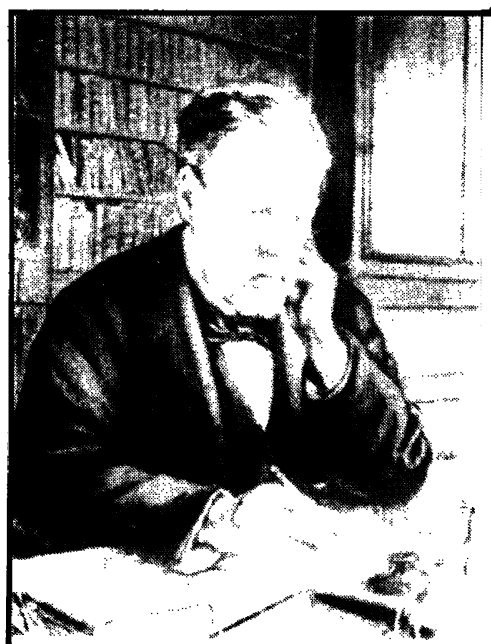

The most original account of Pasteur's science and his personality to appear. . . . a remarkable example of judicious, balanced scholarly treatment of very difficult issues." -Frederic L. Holmes Cloth: E24.95 ISBN 0-691-03442-7

\section{Princeton University Press}

AVALABLE FROM YOUR BOOKSELLER OR DIRECTLY FROM THE PUBLSHER:(609) 883-1759 U.S. • (1243) 779777 U.K./EUROPE

\title{
FRAUD AND MISCONDUCT IN MEDICAL RESEARCH
}

Edited by Stephen Lock and Frank Wells

Fraud exists, both in academic medical research and in drug trials in general practice. This book sets out the evidence, reviewing events since 1975 when the first notorious case of fraud became public knowledge. The problem is viewed from many perspectives, with contributions from a general practitioner, head of an academic unit, contract research company director, statistician, editor and lawyer. Together, their information provides a compelling account of the extent to which fraud and misconduct have been and continue to be practised in medicine. Fraud and Misconduct in Medical Research is a valuable practical text for all researchers - and ultimately anyone who practises medicine.

ISBN 0727907573202 pages 1993

UK £24.95; Overseas $£ 27.00$ (BMA members $£ 22.95 ; £ 25.00$ )

Available from: BMJ PUBLISHING GROUP, P.O. BOX 295, LONDON WC1H 9TE (TEL: 0171.38 .3 6185/6245), any leading bookseller or the BMI Bookshop in BMA House. Please enclose payment with order, or send us full details of your MASTERCARD, VISA or AMERICAN EXPRESS credit card. 
Rare Books \& Manuscripts in the history of

Medicine $\mathcal{E}$ the Sciences

Bought $\bullet$ Sold $\bullet$ Appraised

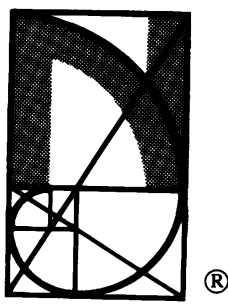

Send for our latest catalogue Jeremy Norman \& Co., Inc.

720 Market Street

San Francisco, California 94102

(415) 781-6402

FAX (415) 781-5507

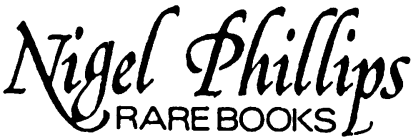

Antiquarian books in the history of medicine and the health sciences.

Please send for my catalogue, or telephone for an appointment when in London.

5 BURLEIGH PLACE PUTNEY

LONDON SW15 6ES

ENGLAND

Tel: 01817882664

Fax: 01817801989

\section{Books concerning the}

History of Medicine, Natural,

\section{Pure and Applied Science}

Catalogues issued-desiderata lists welcome

\section{MICHAEL PHELPS ANTIQUARIAN BOOKS \\ 9 CHELVERTON ROAD - PUTNEY LONDON SW15 1RN - ENGLAND Telephone: 0181-785 6766} Fax: 0181-785 6944

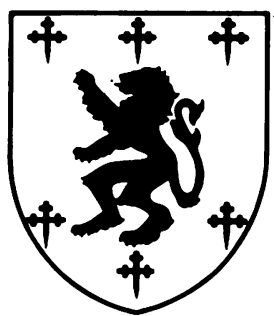

